\title{
Practice-oriented technologies as a means of forming students' communicative competence
}

\section{Tecnologías orientadas a la práctica como medio para formar las competencias comunicativas de los estudiantes}

\author{
Svetlana N. Tatarnitseva \\ Togliatti State University, Togliatti, Russia \\ ORCID: https://orcid.org/0000-0003-4956-3309 \\ Natalya S. Merzlyakova \\ Kumertau branch of Orenburg State University, Kumertau, Russia \\ ORCID: https://orcid.org/0000-0002-9648-1448 \\ Natalia E. Zhitnikova \\ Minin Nizhny Novgorod State Pedagogical University, Russia. \\ ORCID: https://orcid.org/0000-0001-8547-3699 \\ Marina N. Bulaeva \\ Minin Nizhny Novgorod State Pedagogical University, Russia. \\ ORCID: https://orcid.org/0000-0002-9928-9451 \\ Olga T. Chernei $[$ C \\ Minin Nizhny Novgorod State Pedagogical University, Russia \\ ORCID: https://orcid.org/0000-0003-4561-9811
}




\section{Summary}

One of the most important features of professional activity is the ability to build a dialogue, organize business communication. The possession of communicative competencies provides the student with the opportunity to quickly achieve their goals through the implementation of speech turnovers and constructions that comply with the principles and standards of speech etiquette, affecting the establishment and maintenance of the psychological climate in the process of interaction. The purpose of the article is to review the experience of forming communicative competencies with the help of practice-oriented technologies. Requirements for the formation of communicative competencies are reflected in regulatory documents. The competencies under consideration represent the student's ability to build productive professional interaction using various communication methods. We reveal the motivational, cognitive, and active components of communicative competencies, reflecting the desire for interpersonal communication and support for established interaction, the student's understanding of the value of communicative competencies in future professional activities, and the ability to organize effective cooperation. Practice-oriented technologies, including case studies and design, contribute to solving professional problems through group discussions and situation analysis. The study revealed the impact of practice-oriented technologies implemented in higher education institutions on the formation of students' communicative competence.

Key words: case technologies, communication competencies, design technologies, practiceoriented technologies, professional competence.

\section{Resumen}

Una de las características más importantes de la actividad profesional es la capacidad de entablar un diálogo, organizar la comunicación empresarial. La posesión de competencias comunicativas brinda al estudiante la oportunidad de lograr rápidamente sus metas a través de la implementación de cambios de discurso y construcciones que cumplen con los principios y estándares de etiqueta del habla, afectando el establecimiento y mantenimiento del clima psicológico en el proceso de interacción. El propósito del artículo es revisar la experiencia de formar competencias comunicativas con la ayuda de tecnologías orientadas a la práctica. Los requisitos para la formación de competencias comunicativas se reflejan en documentos reglamentarios. Las competencias bajo consideración representan la habilidad del estudiante para construir una interacción profesional productiva usando varios métodos de comunicación. Revelamos los componentes motivacionales, cognitivos y activos de las competencias comunicativas, reflejando el deseo de comunicación interpersonal y el apoyo para la interacción establecida, la comprensión del estudiante del valor de las competencias comunicativas en futuras actividades profesionales y la capacidad de organizar una cooperación efectiva. Las tecnologías orientadas a la práctica, incluidos los estudios de casos y el diseño, contribuyen a resolver problemas profesionales a través de discusiones grupales y análisis de situaciones. El estudio reveló el impacto de las tecnologías orientadas a la práctica implementadas en instituciones de educación superior en la formación de la competencia comunicativa de los estudiantes.

Palabras clave: tecnologías de casos, competencias de comunicación, tecnologías de diseño, tecnologías orientadas a la práctica, competencia profesional.

\section{Introducción}

One of the most important features of professional activity is the ability to build a dialogue, organize business communication (Vaskovskaya et al., 2018). The formation of communicative competencies is an important process in the field of professional education (Tolkanuk, 2019). Communicative competence helps to organize contact with people based on flexible possession of verbal and non-verbal means of communication (Oros, 2018). Possession of communicative competencies provides the student with the ability to quickly achieve goals by implementing 
speech turns and constructions (Aleksieienko-Lemovska, 2019) that correspond to the principles and norms of speech etiquette that affect the establishment and maintenance of a psychological climate in the process of interaction (Vaganova et al., 2019b). Social and business communication allows creating the integrity of communication and interaction through coordinated actions (Prokhorova \& Semchenko, 2018). Students acquire consistency of actions in the process of active practice-oriented activities, where case and project technologies play an important role (Tsarapkina et al., 2019b). They contain a problem that can be solved by combining the experience of each team member (Andriushchenko, 2018). The article presents the experience of implementing practice-oriented technologies as an effective means of forming communicative competencies. We reveal the components of communicative competence: motivational, cognitive, and activity-based (Linkov \& Klinkov, 2018). The motivational component reflects the desire for interpersonal communication and support for established interaction to achieve goals. The cognitive component shows the student's understanding of the value of communicative competencies in future professional activities. The activity component reflects the ability to organize effective cooperation (Pinkovetskaia et al, 2020).

As part of the implementation of project and case technologies, students are divided into small subgroups of 5-7 people, distribute functions among themselves to achieve the overall result. Therefore, all participants are involved in the process of cognitive and communicative activity. These technologies are problematic. Students face a task that is close to a professional one. The process of its implementation is based on the activation of the subject position of students, their interaction, exchange and joint acquisition of new professional experience, experience in discussing and developing solutions to professional problems. There is a positional-professional community-a system of connections, relationships that make possible free professional, activitybased communication, building a constructive dialogue (Arbeláez-Campillo, \& Rojas-Bahamon, 2020).

\section{Theoretical framework}

Assessing the extent of the problem it is necessary to note the diversity and the complexity of studies of communicative competence (Kobernyk et al., 2018). O. A. Andriyenko, revealing the peculiarities of forming General professional competences, emphasizes the fact that communicative competence is an important component of them (Andrienko, 2019a). Among the researchers who touch on the General issues of formation of communicative competences, their essence and structure, we can distinguish I. A. Winter, A. N. Leontiev, M. I. Lisin and other authors who reveal the main aspects of the development of communicative competence.

The concept of communicative competence is considered in different aspects (Gladkov et al., 2019). For example, as a student's ability to communicate adequately in specific communicative situations, the ability to organize speech communication taking into account sociocultural norms of behavior and the expediency of utterance (Halatsyn \& Feshchuk, 2019).

Researchers claim that communicative competence is a multicomponent phenomenon (Petrichev et al., 2018), which includes several elements, including: linguistic, sociolinguistic, sociocultural, discursive, strategic (Vaganova et al., 2019c), social. These elements are interrelated and interdependent (Cirdan, 2019).

A. N. Shchukin defines communicative competence as the ability of students to solve topical every day, educational, and industrial issues using the means of language (Shchukin, 2007). The definition of communicative competence is closely related to socio-cultural aspects and understanding it as a set of social rules, assessments, and values (Klinkov, 2018).

The role of practice-oriented technologies in the formation of communicative competencies is quite large (Grigoriev et al., 2019). Among them, it is worth paying attention to the project, case, dialog, interactive and other problem-oriented technologies (Pliushch, 2018). 
Project technologies occupy leading positions in professional education. They help students acquire the skills of working in a team and allow them to apply their theoretical knowledge in practice in interaction.

Case studies are considered to be one of the most effective ways to teach students the skills to solve typical problems through discussion and analysis of the situation.

Studies of case-technologies are encapsulated in the works of A. M. Dolgorukov, J. P. Surmin and others. The practical possibilities of these technologies are revealed by I. V. Koroleva, E. N. Krasikova, M. V. Goncharova and others.

Implementation of practice-oriented technologies is based on the following principles:

- activity cooperation in cooperation (Bakhareva, 2019);

- unity of development of each student in the group;

- dialogical communication between subjects of the educational process (Chertovskikh, 2019);

- the principle of creating situations of success, choice (Pisarenko, 2019);

- pedagogical interaction (Vaganova et al., 2019a).

Project and case technologies contribute to:

- humanization of relations between participants of educational relations;

- development of the subject position of students (Filchenkova, 2019);

- development of teamwork skills and finding the most rational solutions to the problem;

- development of a creative approach to decision-making (Donetskova, 2019);

- activation of communication abilities (Pichugina \& Zhilyakova, 2019);

- construction of logically correct, reasoned and clear speech;

- development of skills to generalize, analyze, set goals;

- development of skills to negotiate, establish contacts, resolve conflicts;

- development of skills in the design of work results in the form of presentations, reports and reports and their presentation to the public.

As a result of the development of communicative interaction, students acquire the skills to build effective teamwork (Chil Núñez et al, 2020).

Despite the active interest of researchers in the issue of formation of communicative competencies, the relevance of which is noted both at the Russian and international educational levels, there is a lack of scientific knowledge and practices that reveal the potential of practiceoriented technologies in the formation of communicative competencies.

\section{Methodology}

In 2018-2019, we conducted a study of the level of formation of communicative competence of higher school students, which was attended by students of the 1st year in the number of 39 people.

To identify the formation of emotional-reflexive skills, we used the method of diagnostics of the level of empathic and reflexive abilities of V. V. Boyko's personality. Students were asked to answer 35 questions, indicating agreement or disagreement with each specific statement.

Verification of the formation of activity and cognitive components was determined based on the results of project work protection.

Table 1 shows the characteristics of the components of communicative competence. 
Table 1.

Characteristic components communicative competition (in our education)

\begin{tabular}{|l|l|l|}
\hline No. & Component & Characteristic \\
\hline 1 & Motivational & $\begin{array}{l}\text { The student shows initiative, readiness for communication, effective } \\
\text { interaction, acts as a leader in the team, demonstrates the ability to } \\
\text { negotiate with classmates, is resourceful, quickly responds to changing } \\
\text { situations in the team, shows organizational abilities, seeks to expand } \\
\text { business and personal contacts with people, participate in group events }\end{array}$ \\
\hline 2 & Cognitive & $\begin{array}{l}\text { The student knows and understands the importance of communicative } \\
\text { competences in the formation of professional competence, owns a } \\
\text { theoretical knowledge base in the field of future professional activity, the } \\
\text { student has clear ideas about building an effective communication } \\
\text { process in the learning environment to achieve the goals }\end{array}$ \\
\hline 3 & Active & $\begin{array}{l}\text { The student is capable of the consistent implementation of certain actions } \\
\text { in a team, leading to the achievement of set results; capable of } \\
\text { cooperation and joint activities; capable of effective analysis of the } \\
\text { communicative situation }\end{array}$ \\
\hline
\end{tabular}

We have identified three levels of formation of communicative competence. We have shown them in table 2 .

Table 2.

The level of formation of the communicative competence of students of a higher educational institution.

\begin{tabular}{|c|c|c|c|}
\hline Levels & \multicolumn{3}{|c|}{ Structural components of communicative competence } \\
\hline & Motivational & Cognitive & Active \\
\hline Tall & $\begin{array}{l}\text { The student shows } \\
\text { initiative, readiness for } \\
\text { communication, effective } \\
\text { interaction, acts as a leader } \\
\text { in the team, demonstrates } \\
\text { the ability to negotiate } \\
\text { with classmates, is } \\
\text { resourceful, } \\
\text { quickly responds } \\
\text { changes in the situation in } \\
\text { the team, shows } \\
\text { organizational abilities }\end{array}$ & $\begin{array}{l}\text { The student knows } \\
\text { and understands the } \\
\text { importance of } \\
\text { communicative } \\
\text { competencies in the } \\
\text { formation of } \\
\text { professional } \\
\text { competence, owns a } \\
\text { wide theoretical base } \\
\text { of knowledge in the } \\
\text { field of future } \\
\text { professional activity, } \\
\text { the student has clear } \\
\text { ideas about building } \\
\text { an effective } \\
\text { communication } \\
\text { process in the learning } \\
\text { environment to } \\
\text { achieve the goals }\end{array}$ & $\begin{array}{l}\text { The student is capable of the } \\
\text { consistent implementation of } \\
\text { certain actions in a team, } \\
\text { leading to the achievement of } \\
\text { set results; capable of } \\
\text { cooperation and joint } \\
\text { activities; capable of effective } \\
\text { analysis of the communicative } \\
\text { situation }\end{array}$ \\
\hline
\end{tabular}




\begin{tabular}{|c|c|c|c|}
\hline Middle & $\begin{array}{l}\text { The student shows } \\
\text { initiative, readiness for } \\
\text { communication, aims at } \\
\text { the result, if necessary, } \\
\text { acts as a leader in the team, } \\
\text { demonstrates the ability to } \\
\text { negotiate with classmates, } \\
\text { is resourceful, reacts to } \\
\text { and changes in the } \\
\text { situation in the team }\end{array}$ & $\begin{array}{l}\text { The student knows } \\
\text { and understands the } \\
\text { importance of } \\
\text { communicative } \\
\text { competencies in the } \\
\text { formation of } \\
\text { professional } \\
\text { competence, owns a } \\
\text { sufficient knowledge } \\
\text { base in the field of } \\
\text { future professional } \\
\text { activities, the student } \\
\text { has ideas about } \\
\text { building an effective } \\
\text { communication } \\
\text { process in the learning } \\
\text { environment to } \\
\text { achieve the goals }\end{array}$ & $\begin{array}{l}\text { The student may, if } \\
\text { necessary, to carry out the } \\
\text { command operation, leading } \\
\text { to the achievement of } \\
\text { results; capable } \\
\text { cooperation and joint } \\
\text { activities; capable of effective } \\
\text { analysis of the communicative } \\
\text { situation }\end{array}$ \\
\hline Low & $\begin{array}{l}\text { The student does not show } \\
\text { initiative and willingness } \\
\text { to communicate, as a rule, } \\
\text { it is not interested in the } \\
\text { result and the leader } \\
\text { position, can to used to } \\
\text { say to classmates }\end{array}$ & $\begin{array}{l}\text { The student has a } \\
\text { minimum knowledge } \\
\text { base in the field of } \\
\text { future professional } \\
\text { activity, the student } \\
\text { has ideas about the } \\
\text { construction of the } \\
\text { communication } \\
\text { process in the learning } \\
\text { environment to } \\
\text { achieve the goals }\end{array}$ & $\begin{array}{l}\text { Carries out the command } \\
\text { operation, leading to the } \\
\text { achievement of } \\
\text { results; capable of joint } \\
\text { activities; communicative } \\
\text { situation analysis causes } \\
\text { difficulties }\end{array}$ \\
\hline
\end{tabular}

\section{Results and discussion}

Students were involved in active group activities using practice-oriented technologies.

Project technologies provide a solution to a specific problem that requires attracting students' knowledge not from one professional discipline, but from different areas of knowledge, which activates their creative thinking and research skills. By joining groups, students study a variety of materials. Joint work encourages students to search for additional information and evaluate the results obtained. Discussion of intermediate results, discussions, brainstorming sessions, acquire a new quality, since they include not only material from official information sources and the opinions of well-known researchers, but also various points of view of participants in the educational process, the interpretation of facts and phenomena. Working with information in the process of implementing project and case technologies requires selecting the necessary facts and arguments to defend your point of view.

Students took part in dialogues, discussions, discussion of the results of project activities, cases, made presentations and reports. Collaboration to achieve a common goal within the framework of project implementation develops students ' ability to listen to and accept the partner's opinion, argue their point of view, and compromise. Project development is also carried out outside of the educational institution. Students continue to interact with the help of digital technology. Development and protection of the project take place in active interaction with the help of chats, forums, e-mail and other modern messengers that provide rapid interaction.

The description of the case contains a problem, as well as direct or indirect contradictions that students will have to solve. The tasks assigned to students do not have an unambiguous 
solution. Students develop their own algorithm of actions during discussions. The successful solution of the problem serves as an incentive for students to acquire additional communicative competencies in order to carry out effective professional activities. Testing their communication skills in the process of discussion allows students to discover their weaknesses and improve them.

The student in the process of performing practice-oriented tasks makes a conscious choice of alternative communication strategies and tactics in solving problem situations, builds a coordinated algorithm of actions to achieve goals. A rich communicative environment immerses the student in professionally and personally meaningful communication.

An important aspect of implementing project and case technologies is the ability to publicly present a ready-made intellectual product and show its advantages. At the same time, the student learns to accept criticism and prove their point of view with reasoned arguments.

Table 3 shows the results of statistical data processing to identify the level of formation of the communicative competence "readiness to model the strategy and technology of communication for solving specific professional and pedagogical tasks". As a result of identifying the average component for all formed components of communicative competence, we received the following data.

Table 3.

The results of statistical data processing to identify the level of formation of communicative competence (as part of our study)

\begin{tabular}{|c|c|c|c|c|c|c|}
\hline Levels & \multicolumn{3}{|c|}{ Structural components of students' communicative competence } \\
\hline & \multicolumn{2}{|c|}{ Motivational } & \multicolumn{2}{c|}{ Cognitive } & \multicolumn{2}{c|}{ Active } \\
\hline & Before & After & Before & After & Before & After \\
\hline Low & 18,3 & 54,1 & 25,3 & 40,8 & 8,2 & 50,6 \\
\hline Middle & 17,43 & 30,1 & 32,7 & 46,7 & 23,5 & 40,3 \\
\hline High & 23,1 & 29,2 & 35,4 & 36,4 & 39,4 & 45,6 \\
\hline
\end{tabular}

Analyzing the obtained values of the levels of formation of communicative competence before and after the study, we can conclude that after the introduction of practice-oriented technologies in the training of students, the percentage of students with a high level of formation of communicative competence has significantly increased. If at the beginning of the study, it was $35 \%$, then at the end $-45 \%$. The implemented technologies made it possible to change the quality of training and organize the effective interaction of students. The average value for the motivational level at the end of the study is 54.1 (low level), 30.1 (medium level), and 29.2 (high level). The cognitive component at the end of the study: low level-40.8, average-46.7, high-36.4, average values of the activity component: 50.6, 40.3, 45.6, respectively. The results obtained at the end of the study show a significant difference in values compared to the beginning of the study.

\section{Conclusions}

The research allowed us to reveal the possibilities of practice-oriented technologies in the formation of communicative competencies of students of higher education institutions.

Implementation of practice-oriented technologies contributes to more solid assimilation of information through specific actions and events that are close to real professional activity. Creative activity in the process of performing project and case tasks determines the involvement in the communicative interaction of each student. Independent solution of tasks allows students to quickly search for a joint solution. 
Discussion of intermediate results, discussions, brainstorming, acquire a new quality in the process of group activity, since they include not only material from official information sources and the opinions of famous researchers, but also various points of view of participants in the educational process.

With the introduction of practice-oriented technologies in the educational process, the number of students with a high level of formation of motivational, cognitive and activity components of the competence in question has increased, which indicate the presence of a value attitude to communicative competence as part of professional competence, expressed in the desire to support active communication activities; knowledge of communication techniques for organizing better interaction; the ability to build effective team activities.

The results of the research allowed us to identify the positive impact of project and case technologies on the formation of students' communicative competence.

Conflict of interests: The authors declare that they have no conflicts of interest.

Authors' contribution: The authors have participated in the research process, in the writing of the work and in the analysis of the documents.

\section{Bibliographic references}

Andrienko, O.A. (2019a). On the need to apply gaming training technologies. Balkan Scientific Review, 2 (4), 5-8.

Andrienko, O.A. (2019b). Modern educational technologies: technology of self-presentation. Balkan Scientific Review, 1(3), 5-7.

Andriushchenko, T. K. (2018). Personal aspects of pedagogue's innovative culture, Scientific Vector of the Balkans, 1, 13-16.

Aleksieienko-Lemovska, L.V. (2019). The activity approach as a basis for preschool teachers' methodological activities, Humanitarian Balkan Research, 3, 4(6), 10-14.

Arbeláez-Campillo, D.F., \& Rojas-Bahamon, M.J (2020). "Pandemics in globalization times". Amazonia Investiga, 9(27), 3-4. https://amazoniainvestiga.info/index.php/amazonia/article/view/1189

Bakharev, N. P. (2019). Creativity - a prerequisite for the formation of professional competences in specialists of technical direction of training. Scientific Vector of the Balkans, 3, 4 (6), $17-21$.

Cirdan, A.P. (2019). Innovative technologies of professional training of future economists in the system of continuous education. Humanitarian Balkan Research, 2(4), 27-30.

Chertovskikh, O.O. (2019). Prospects for the use of digital resources in education. Baltic Humanitarian Journal. 8, 4 (29), 184-187.

Chil Núñez, I., Escalona Arranz, J., Molina Bertrán, S., Dutok Sánchez, C., Arias Ramos, D., Pérez Rondón, L., Ochoa Pacheco, A., \& Picanço Souto, R. (2020). Perfeccionamiento de la estrategia curricular de medio ambiente de la carrera de ciencias farmacéuticas de la Universidad de Oriente, Cuba. Revista Científica Del Amazonas, 3(5), 6-17. https://revistadelamazonas.info/index.php/amazonas/article/view/24 
Donetskova, O.YU. (2019). Modernization of the modern education system in Russia. Baltic Humanitarian Journal, 8, 2 (27), 37-39.

Filchenkova, I.F. (2019). Educational management of innovative activity of teachers as an object of pedagogical research. Vestnik of Minin University, 2019.7 (4), 3.

Grigoriev, S. G., Shabunina, V. A., Tsarapkina, Ju. M., \& Dunaeva, N. V. (2019). Electronic library system as a means of self-development of students of digital generation $\mathrm{Z}$ (on the example of studying the course "Basics of the counselor activity"). Scientific and technical libraries. No. 7. Pp. 78-99. 29.

Gladkov, A.V., Vaganova, O.I., \& Prokhorova, M.P. (2019). Modern pedagogical technologies as a means of enhancing educational motivation. Baltic Humanitarian Journal. 8, 1 (26). 274-276.

Halatsyn, K.A., \& Feshchuk, A.M. (2019). Diagnosing motivational-and-valuable component of the communicative culture of students in higher technical educational institutions, Balkan Scientific Review, 3, 2 (4), 17-20.

Klinkov, G.T. (2018). The specificity of manifestation of pedagogical communication as a special construct. Scientific Vector of the Balkans, 1, 51-52.

Kotlyar, I.A. (2008). About the early studies of L.I. Bozhovich. Modern problems of personality psychology: theory and practice.

Kobernyk, O.M., Stetsenko, N.M., Boichenko, V.V., \& Pryshchepa, S.M. (2018). Improving professional and pedagogical training of future teachers by moodle platforms (On the example of the course "Pedagogy"). Scientific Vector of the Balkans, 1, 5-7.

Linkov, A.Y., \& Klinkov, G.T. (2018). Person-oriented learning based on its sociological derivation. Scientific Vector of the Balkans, 1, 5-7.

Oros, I.I. (2018) The role of international connections in the development of the adult education system. Humanitarian Balkan Research, 1, 57-59.

Osadchenko, I.I. (2019). Key concepts of situational training technology in preparing future teachers. Scientific Vector of the Balkans, 1 (3), 46-49.

Pliushch, V.M. (2018). Independent work of students as a factor of improving education quality. Balkan Scientific Review, 1, 69-71.

Prokhorova, M.P., \& Semchenko, A.A. (2018). Involving of trainees-future teachers of professional training in project activities in the discipline. Vestnik of Minin University, 6, (2), 6 .

Pichugina, G. A., \& Zhilyakova, D. A. (2019) Structuring the organization of the process of creativity. Scientific Vector of the Balkans, 3, 3 (5), 55-58.

Pinkovetskaia, I.S, Arbeláez-Campillo, D.F., Rojas-Bahamón, M.J., \& Veas Iniesta. D. (2020). "Motivation of new entrepreneurs in modern economies" Amazonia Investiga, 9(29), 368-373. https://amazoniainvestiga.info/index.php/amazonia/article/view/1403

Petrichev, P. V., Masyuk, N. N., \& Bushueva, M. A. (2018). Method of estimation of the effectiveness of the partnership russian universities with foreign educational 
organizations. Azimuth of Scientific Researches: Economics and Management, 7, 3 (24), 229-232.

Pisarenko, D. A. (2019). Evaluation of extracurricular activities of university students with a competency-based approach. Scientific Vector of the Balkans, 3, 3 (5), 37-40.

Shchukin, A. N. (2007). Linguodidactic encyclopedic dictionary / A. N. Shchukin. M.: Astrel: ACT: Keeper, $118 \mathrm{p}$.

Tsarapkina, Ju.M., Petrova, M.M., Mironov, A.G., Morozova, I.M., \& Shustova, O.B. (2019a). Robotics as a basis for Informatization of education in children's health camp. Amazonia Investiga, 8 (20). $115-123$ https://www.amazoniainvestiga.info/index.php/amazonia/article/view/70

Tolkanuk, Z. A. (2019). Professional self-determination of youth as a factor of training of a competent specialist. Balkan Scientific Review, 3, 2 (4), 57-59.

Tsarapkina, Ju. M., Dunaeva, N. V., \& Kireicheva, A. M. (2019b). Application of BYOD technology in education on the example of Lecture Racing mobile application. Informatics and Education, 9 (308), 56-64.

Vaganova, O.I., Ilyashenko, L.I., Smirnova, Zh.V., Bystrova, N.V., \& Kaznacheeva, S.N. (2019a). Students' creative abilities development in higher educational institution. Amazonia $\begin{array}{llll}\text { Investiga, } & 8 & \text { 701-710. }\end{array}$ https://www.amazoniainvestiga.info/index.php/amazonia/article/view/822

Vaganova, O.I., Rudenko, I.V., Markova, S.M., Smirnova, Zh.V., \& Kutepov, M.M. (2019b). The use of educational video materials in educational process of a higher educational institution. Amazonia Investiga, 8 (22), 216-222. https://www.amazoniainvestiga.info/index.php/amazonia/article/view/308

Vaganova, O.I., Livshits, Yu.A., Aleshugina, E.A., Smirnova, Zh.V., \& Kutepova, L.I. (2019c). Experience in developing electronic glossary in a higher education institution. Amazonia Investiga, $\quad 8 \quad(22)$,

247253. https://www.amazoniainvestiga.info/index.php/amazonia/article/view/421

Vaskovskaya, G.A. (2018). Features of implementation of pedagogical technologies of profile training. Balkan Scientific Review, 1, 76-79. 